\title{
The implausible "in vivo" role of hydrogen peroxide as an antimicrobial factor produced by vaginal microbiota
}

\author{
Gilda Tachedjian ${ }^{1,2,3,4^{*}}$, Deirdre E. O'Hanlon ${ }^{5,6}$ and Jacques Ravel ${ }^{5,6^{*}}$ (D)
}

\begin{abstract}
In the cervicovaginal environment, the production of hydrogen peroxide $\left(\mathrm{H}_{2} \mathrm{O}_{2}\right)$ by vaginal Lactobacillus spp. is often mentioned as a critical factor to the in vivo vaginal microbiota antimicrobial properties. We present several lines of evidence that support the implausibility of $\mathrm{H}_{2} \mathrm{O}_{2}$ as an "in vivo" contributor to the cervicovaginal milieu antimicrobial properties. An alternative explanation is proposed, supported by previous reports ascribing protective and antimicrobial properties to other factors produced by Lactobacillus spp. capable of generating $\mathrm{H}_{2} \mathrm{O}_{2}$. Under this proposal, lactic acid rather than $\mathrm{H}_{2} \mathrm{O}_{2}$ plays an important role in the antimicrobial properties of protective vaginal Lactobacillus spp. We hope this commentary will help future research focus on more plausible mechanisms by which vaginal Lactobacillus spp. exert their antimicrobial and beneficial properties, and which have in vivo and translational relevance.
\end{abstract}

\section{Main text}

In 1892, Albert Doderlein first described the presence of Gram-positive bacilli in the vagina of healthy reproductive-age women with low vaginal $\mathrm{pH}$ [1]. He considered the anti-staphylococci activities of the vaginal bacilli and the bactericidal action of the vaginal secretions to be due to the lactic acid produced by the bacilli [2]. His findings and those of others led to the proposal that vaginal acidification by lactic acid producing Lactobacillus spp. is the primary mechanism by which these bacteria contribute to the protection against reproductive tract pathogens $[1,2]$. In addition to releasing organic acid metabolites (e.g., lactic acid) known to provide antimicrobial and immunomodulatory properties, Lactobacillus spp. can outcompete other bacteria at the epithelial mucosa as well as releasing bacteriocins, surfactants, antimicrobial proteins, or peptides [3-5]. In the 1990s, Lactobacillus species that produced $\mathrm{H}_{2} \mathrm{O}_{2}$ gained favour as being antimicrobial and synonymous with the presence of an optimal protective vaginal microbiota in reproductive-age women [6]. The protective role ascribed to $\mathrm{H}_{2} \mathrm{O}_{2}$ largely

\footnotetext{
* Correspondence: gilda.tachedjian@burnet.edu.au; jravel@som.umaryland.edu

${ }^{1}$ Disease Elimination Program, Life Sciences Discipline, Burnet Institute, 85 Commercial Rd, Melbourne, Victoria 3004, Australia

${ }^{5}$ Institute for Genome Sciences, University of Maryland School of Medicine, 801 West Baltimore Street, Baltimore, MD 21201, USA

Full list of author information is available at the end of the article
}

stems from epidemiological studies linking the presence in the vagina of $\mathrm{H}_{2} \mathrm{O}_{2}$-producing Lactobacillus spp. with a decreased risk for bacterial vaginosis (BV) [6-9], sexually transmitted infections $[10,11]$, as well as adverse birth outcomes [12], compared to women harboring non$\mathrm{H}_{2} \mathrm{O}_{2}$-producing vaginal Lactobacillus. Unfortunately, these epidemiological observations were interpreted into the now widely accepted statement that "in vivo, Lactobacillus spp. exerts its antimicrobial properties through the production of $\mathrm{H}_{2} \mathrm{O}_{2}$ ". While we do not dispute these epidemiological studies, the notion that in vivo $\mathrm{H}_{2} \mathrm{O}_{2}$ production by vaginal Lactobacillus spp. is an important factor contributing to the antimicrobial properties of these species is highly unlikely in the context of physiological conditions present in the lower female reproductive tract (FRT). In this commentary, several lines of evidence are presented that support the implausibility of "in vivo" $\mathrm{H}_{2} \mathrm{O}_{2}$ as an antimicrobial factor in the cervicovaginal environment. An alternative explanation is proposed, supported by previous reports ascribing protective and antimicrobial properties to other factors produced by Lactobacillus spp. capable of generating $\mathrm{H}_{2} \mathrm{O}_{2}$. Under this proposal, lactic acid rather than $\mathrm{H}_{2} \mathrm{O}_{2}$ plays an important role in the antimicrobial properties of protective vaginal Lactobacillus spp.

A fact that is not disputed is that in any microbial system, no matter the mechanism (pyruvate oxidase, lactate 
oxidase or NADH oxidase or NADH-dependent flavin mononucleotide reductase) [13], $\mathrm{O}_{2}$ is required to produce $\mathrm{H}_{2} \mathrm{O}_{2}$, and in large amounts to achieve $\mathrm{H}_{2} \mathrm{O}_{2}$ concentrations necessary to have antimicrobial activity in the vaginal environment [14-16]. Thus, a major question is how much oxygen is present to support this reaction in the vagina. The cervicovaginal environment is microaerobic (hypoxic) [17]. The mean cervicovaginal $\mathrm{O}_{2}$ levels range from 15 to $35 \mathrm{mmHg}(2 \%)$, which is much lower than atmospheric levels of $160 \mathrm{mmHg}$ (21\%) [17-19]. Conversely, the cervicovaginal $\mathrm{CO}_{2}$ partial pressure ranges from 35 to $55 \mathrm{mmHg}$ (or $5 \%$ ), which is considerably higher than atmospheric levels (i.e., $5 \mathrm{mmHg}, 0.04 \%$ ) [17-19]. Only transient increases in $\mathrm{O}_{2}$, that rarely achieve atmospheric levels, have been reported upon or after tampon or diaphragm insertion, sexual arousal $[17,18,20,21]$, and probably sexual intercourse. Vaginal Lactobacillus spp., like most Lactobacillus spp., are aerotolerant anaerobes and some do produce $\mathrm{H}_{2} \mathrm{O}_{2}$ when propagated under aerobic conditions, such as aeration by flask shaking $[14,15]$. Conversely, lactic acid is predominately produced and at high concentrations under hypoxic conditions $[19,22]$. Consistent with these in vitro observations and the low vaginal $\mathrm{O}_{2}$ levels measured in vivo, $\mathrm{H}_{2} \mathrm{O}_{2}$-producing vaginal Lactobacillus spp. have been shown to make little or no $\mathrm{H}_{2} \mathrm{O}_{2}$ in the context of the hypoxic cervicovaginal environment $[16,23]$.

The reported production of $\mathrm{H}_{2} \mathrm{O}_{2}$ by vaginal Lactobacillus spp. is measured using artificial in vitro conditions that do not recapitulate the hypoxic cervicovaginal environment $[6,14]$. Consistent with this observation, the literature assigning an antimicrobial role for $\mathrm{H}_{2} \mathrm{O}_{2}$ describe experiments where Lactobacillus isolates are cultured under aerobic conditions to facilitate production and detection of $\mathrm{H}_{2} \mathrm{O}_{2}[6,13-15,24-26]$ (Table 1). Antimicrobial activity of $\mathrm{H}_{2} \mathrm{O}_{2}$ is observed in vitro in protein-free salt solutions, conditions that are not consistent with those in the cervicovaginal environment and an in vivo antimicrobial role for $\mathrm{H}_{2} \mathrm{O}_{2}$. Supporting this conclusion is the finding that $\mathrm{H}_{2} \mathrm{O}_{2}$ is inactivated by the reducing capabilities of cervicovaginal fluid (CVF) and semen [16, 23]. $\mathrm{H}_{2} \mathrm{O}_{2}$ measured in fully aerobic CVF is only $23 \pm 5 \mu \mathrm{M}$ [16]; however, CVF and semen completely reduce $1 \mathrm{mM}$ and $10 \mathrm{mM}$ added $\mathrm{H}_{2} \mathrm{O}_{2}$, respectively [16]. The addition of as little as $1 \%$ CVF supernatant completely abolishes the pathogen-inactivation by aerobically grown $\mathrm{H}_{2} \mathrm{O}_{2}$-producing Lactobacillus spp. [16] demonstrated by Klebanoff et al. [6]. In in vitro assays, physiological concentrations of $\mathrm{H}_{2} \mathrm{O}_{2}(<100 \mu \mathrm{M})$ found in vaginal fluids, even when potentiated with myeloperoxidase, fail to inactivate bacterial vaginosis associated microbes, as well as bacterial (Neisseria gonorrhoeae) and viral (HSV-2) pathogens $[16,23]$. Supra-physiological levels $(10 \mathrm{mM})$ of $\mathrm{H}_{2} \mathrm{O}_{2}$ inactivate only one of $17 \mathrm{BV}$-associated bacterial species tested while completely inactivating four major vaginal
Lactobacillus spp., L. crispatus, L. gasseri, L. jensenii, and $L$. iners [23]. These findings do not support an antimicrobial role for $\mathrm{H}_{2} \mathrm{O}_{2}$ in the cervicovaginal environment; however, the association between $\mathrm{H}_{2} \mathrm{O}_{2}$-producing strains of Lactobacillus spp. and favorable reproductive and urogenital outcomes may represent an in vitro marker for vaginal strains with beneficial properties. We put forth that other functions associated with these isolates capable of producing $\mathrm{H}_{2} \mathrm{O}_{2}$ in vitro must be responsible for their beneficial properties [3, $14,24,27]$. In support of this proposal are issues with in vitro measurement of $\mathrm{H}_{2} \mathrm{O}_{2}$ production, which can be affected by growth kinetics. As such, a third of non- $\mathrm{H}_{2} \mathrm{O}_{2}$ producing strains were shown to 'convert' to $\mathrm{H}_{2} \mathrm{O}_{2}$ producers when the nutritional medium was reformulated [25] and in another study, $44 \%$ of non- $\mathrm{H}_{2} \mathrm{O}_{2}$-producing strains became producers when the time allowed for $\mathrm{H}_{2} \mathrm{O}_{2}$ production was increased from 30 to $60 \mathrm{~min}$ [12], vividly demonstrating that the difference is one of rate rather than absolute ability. Consistent with these findings, and the hypothesis that $\mathrm{H}_{2} \mathrm{O}_{2}$ is preferentially produced through $\mathrm{NADH}$-dependent flavin mono-nucleotide reductase in lactic acid bacteria [13, 28, 29], an analysis of $125 \mathrm{~L}$. iners genomes assembled from metagenomics datasets, showed that all genomes carry both genes found responsible for $\mathrm{H}_{2} \mathrm{O}_{2}$ production in L. johnsonii [13] and other members of the $L$. acidophilus group (data not shown). These finding severely weaken the association between production of $\mathrm{H}_{2} \mathrm{O}_{2}$ by vaginal Lactobacillus species and protection against BV, STI, and other adverse outcomes.

Vaginal Lactobacillus spp. produces lactic acid through the fermentation of polysaccharides, including glucose,

Table 1 Concentrations of hydrogen peroxide and lactic acid produced by Lactobacillus spp. under different conditions and concentrations necessary to inactivate HIV and BV-associated bacteria

\begin{tabular}{|c|c|c|c|c|}
\hline Conditions & $\mathrm{H}_{2} \mathrm{O}_{2}[\mathrm{mM}]$ & & $\begin{array}{l}\text { Lactic acid } \\
{[\mathrm{mM}]}\end{array}$ & \\
\hline $\begin{array}{l}\text { Culture medium under hypoxic } \\
\text { conditions }\end{array}$ & Undetectable & [46] & $160-250$ & $\begin{array}{l}{[22,} \\
47]\end{array}$ \\
\hline Aerated culture medium & $3.34-4.39$ & {$[46]$} & 45 & {$[22]$} \\
\hline $\begin{array}{l}\text { Lactobacillus-dominated CVF } \\
\text { under hypoxic conditions }\end{array}$ & Undetectable & [16] & 110 & [23] \\
\hline $\begin{array}{l}\text { Aerated Lactobacillus-dominated } \\
\text { CVF }\end{array}$ & 0.023 & {$[16]$} & 63 & [23] \\
\hline $\begin{array}{l}\text { Inactivation of HIV in culture } \\
\text { medium }\end{array}$ & 5 & [48] & 33 & [32] \\
\hline $\begin{array}{l}\text { Inactivation of BV-associated } \\
\text { bacteria in culture medium }\end{array}$ & 10 & {$[23]$} & $55-110$ & [23] \\
\hline $\begin{array}{l}\text { Inactivation of HIV in the } \\
\text { presence of CVF }\end{array}$ & Undetermined & & $33-110$ & [32] \\
\hline $\begin{array}{l}\text { Inactivation of BV-associated } \\
\text { bacteria in the presence of CVF }\end{array}$ & $>1000$ & {$[23]$} & $55-110$ & [23] \\
\hline $\begin{array}{l}\text { Inactivation of Lactobacillus in } \\
\text { culture medium }\end{array}$ & $>1000$ & {$[23]$} & $>1000$ & [23] \\
\hline
\end{tabular}


under hypoxic conditions [30, 31]. In women of reproductive-age, harboring Lactobacillus-dominated vaginal microbiota, measurement of the average concentration of lactic acid in cervicovaginal fluid (CVF) under hypoxic conditions is $1.0 \pm 0.2 \%(w / v)$, a concentration associated with a low $\mathrm{pH}$ between 3.5 and 4.5 [19] (Table 1). The strong inverse correlation between $\mathrm{pH}$ and lactic acid levels indicates that lactic acid is the main acidifier in the lower FRT [19]. Lactic acid has been shown to have antimicrobial activity [32,33], as well as anti-inflammatory properties on cervicovaginal epithelial cells, which together support a role in lowering the risk of sexually transmitted infection acquisition and transmission [34, 35]. In vitro and at physiological concentrations (55-111 $\mathrm{mM})$ and $\mathrm{pH}$ (4.5), lactic acid inactivates 17 different BV-associated bacteria, while not affecting the viability of four vaginal Lactobacillus spp. [23]. Under in vitro anaerobic conditions, lactic acid produced by $L$. crispatus and $L$. gasseri, but not $\mathrm{H}_{2} \mathrm{O}_{2}$, was shown to inactivate Neisseria gonorrhoeae [36], Chlamydia trachomatis [22, 37] as well as Escherichia coli [38]. Lactic acid produced by $L$. crispatus inhibits $N$. gonorrhoeae and Gardnerella vaginalis as demonstrated in a porcine vaginal mucosa explant model [39].

Interestingly, Antonio et al. found that 94, 95, and 70\% of $L$. crispatus, $L$. jensenii and $L$. gasseri isolates, respectively, but only $9 \%$ of $L$. iners strains produce $\mathrm{H}_{2} \mathrm{O}_{2}$ in vitro [40]. Notably, the D-isomer of lactic acid is exclusively produced by $L$. crispatus, L. jensenii and L. gasseri, and not $L$. iners [41, 42], and while not extensively tested, has been shown to be associated with immobilisation of HIV1 in mucus [43], as well as being implicated in preventing vaginal bacteria traversing the cervix to initiate upper genital tract infections [41]. Thus, the lack of $\mathrm{H}_{2} \mathrm{O}_{2}$-production may represent less beneficial strains of Lactobacillus spp. that do not produce high quantities of lactic acid and thus fail to acidify the vagina to low $\mathrm{pH}[29,41]$ or lack the ability to produce D-lactic acid, which appears to be an essential isomer. Further, Tomás et al. [44] found that strains of vaginal Lactobacillus species producing $\mathrm{H}_{2} \mathrm{O}_{2}$ in vitro also produced significantly more lactic acid than non- $\mathrm{H}_{2} \mathrm{O}_{2}$-producing strains. Lastly, slow growth or metabolic rates might limit the competitiveness of some Lactobacillus spp. leading to lack of dominance when faced with intrinsic (e.g., menses) and extrinsic (e.g., sex) disturbances, thus frequently transitioning to BV-like microbiota comprising a wide array of strict and facultative anaerobes [45] and should also be considered.

\section{Conclusion}

The scientific literature does not support an in vivo antimicrobial role for $\mathrm{H}_{2} \mathrm{O}_{2}$ produced by vaginal Lactobacillus spp. The perpetuation of this concept lacks scientific justification. Definitive clarification of the lack of in vivo antimicrobial role for $\mathrm{H}_{2} \mathrm{O}_{2}$ is critical to focus on more plausible mechanisms by which vaginal Lactobacillus spp. exert their antimicrobial and beneficial properties, including that of lactic acid. This goal could be achieved by examining, but not limited to, the following:

1) In vitro studies examining the antimicrobial role of Lactobacillus spp. metabolites or other factors could consider-and ideally recapitulate-the conditions generally prevailing in vivo, e.g., hypoxia and high antioxidant capacity among others.

2) The direct antimicrobial activity of any factor, whether endogenous products of Lactobacillus spp. or exogenous formulation, could be confirmed in the presence of CVF.

3) Epidemiological studies associating vaginal microbiota and reproductive health outcomes could incorporate quantification of putative antimicrobial factors or activities of Lactobacillus spp. in ex vivo CVF samples in prospective study designs.

A shift of focus on mechanisms with translational relevance is key for the evidence-based selection of Lactobacillus spp. or Lactobacillus metabolites, and other factors, in efforts to develop and test novel biotherapeutics for the female reproductive tract.

\section{Funding}

GT is supported by the National Health and Medical Research Council of Australia (NHMRC) Senior Research Fellowship APP1117748 and NHMRC Project Grant APP1088564. GT gratefully acknowledges the contribution of the Victorian Operational Infrastructure Support Program received by the Burnet Institute. JR is supported by National Institute for Allergy and Infectious Diseases of the National Institutes of Health under award number U19AI084044 and R01NR015495.

\section{Authors' contributions}

GT, DEO and JR wrote the manuscript. All authors read and approved the final manuscript.

\section{Competing interests}

The authors declare that they have no competing interests.

\section{Publisher's Note}

Springer Nature remains neutral with regard to jurisdictional claims in published maps and institutional affiliations.

\section{Author details}

${ }^{1}$ Disease Elimination Program, Life Sciences Discipline, Burnet Institute, 85 Commercial Rd, Melbourne, Victoria 3004, Australia. ${ }^{2}$ Department of Microbiology, Monash University, Clayton, VIC 3168, Australia. ${ }^{3}$ Department of Microbiology and Immunology, The University of Melbourne, The Peter Doherty Institute for Infection and Immunity, Melbourne, VIC 3010, Australia. ${ }^{4}$ School of Science, College of Science, Engineering and Health, RMIT University, Melbourne, Victoria 3000, Australia. Institute for Genome Sciences, University of Maryland School of Medicine, 801 West Baltimore Street, Baltimore, MD 21201, USA. ${ }^{6}$ Department of Microbiology and Immunology, University of Maryland School of Medicine, Baltimore, MD 21201, USA. 
Received: 11 January 2018 Accepted: 30 January 2018

\section{Published online: 06 February 2018}

\section{References}

1. Doderlein A. Das Scheidensekret und seine Bedeutung fur das Peurperalfieber. Zentbl Bakteriol Microbiol Hyg Abt. 1892;11:699.

2. Lash AF, Kaplan BA. A study of doderlein's vaginal bacillus. J Infect Dis. 1926; 38:333-40.

3. Aroutcheva A, Gariti D, Simon M, Shott S, Faro J, Simoes JA, Gurguis A, Faro S. Defense factors of vaginal lactobacilli. Am J Obstet Gynecol. 2001;185(2):375-9.

4. Tachedjian G, Aldunate M, Bradshaw CS, Cone RA. The role of lactic acid production by probiotic lactobacillus species in vaginal health. Res Microbiol. 2017;168(9-10):782-92.

5. Yang SC, Lin CH, Sung CT, Fang JY. Antibacterial activities of bacteriocins: application in foods and pharmaceuticals. Front Microbiol. 2014:5:241.

6. Klebanoff SJ, Hillier SL, Eschenbach DA, Waltersdorph AM. Control of the microbial flora of the vagina by H2O2-generating lactobacilli. J Infect Dis. 1991;164(1):94-100.

7. Hawes SE, Hillier SL, Benedetti J, Stevens CE, Koutsky LA, Wolner-Hanssen P, Holmes KK. Hydrogen peroxide-producing lactobacilli and acquisition of vaginal infections. J Infect Dis. 1996;174(5):1058-63.

8. Cherpes TL, Hillier SL, Meyn LA, Busch JL, Krohn MA. A delicate balance: risk factors for acquisition of bacterial vaginosis include sexual activity, absence of hydrogen peroxide-producing lactobacilli, black race, and positive herpes simplex virus type 2 serology. Sex Transm Dis. 2008;35(1):78-83.

9. Hillier SL, Krohn MA, Rabe LK, Klebanoff SJ, Eschenbach DA. The normal vaginal flora, $\mathrm{H} 2 \mathrm{O} 2$-producing lactobacilli, and bacterial vaginosis in pregnant women. Clin Infect Dis. 1993;16(Suppl 4):S273-81.

10. Hillier SL, Krohn MA, Klebanoff SJ, Eschenbach DA. The relationship of hydrogen peroxide-producing lactobacilli to bacterial vaginosis and genital microflora in pregnant women. Obstet Gynecol. 1992;79(3):369-73.

11. Gupta K, Stapleton AE, Hooton TM, Roberts PL, Fennell CL, Stamm WE. Inverse association of $\mathrm{H} 2 \mathrm{O} 2$-producing lactobacilli and vaginal Escherichia Coli colonization in women with recurrent urinary tract infections. J Infect Dis. 1998;178(2):446-50.

12. Kim YH, Kim CH, Cho MK, Na JH, Song TB, Oh JS. Hydrogen peroxideproducing lactobacilli in the vaginal flora of pregnant women with preterm labor with intact membranes. Int J Gynaecol Obstet. 2006;93(1):22-7.

13. Hertzberger R, Arents J, Dekker HL, Pridmore RD, Gysler C, Kleerebezem M, de Mattos MJ. $\mathrm{H}(2) \mathrm{O}(2)$ production in species of the lactobacillus acidophilus group: a central role for a novel NADH-dependent flavin reductase. Appl Environ Microbiol. 2014;80(7):2229-39.

14. Martin R, Suarez JE. Biosynthesis and degradation of $\mathrm{H} 2 \mathrm{O} 2$ by vaginal lactobacilli. Appl Environ Microbiol. 2010;76(2):400-5

15. Ocana VS, Pesce de Ruiz Holgado AA, Nader-Macias ME. Selection of vaginal H2O2-generating lactobacillus species for probiotic use. Curr Microbiol. 1999;38(5):279-84.

16. O'Hanlon DE, Lanier BR, Moench TR, Cone RA. Cervicovaginal fluid and semen block the microbicidal activity of hydrogen peroxide produced by vaginal lactobacilli. BMC Infect Dis. 2010;10:120.

17. Hill DR, Brunner ME, Schmitz DC, Davis CC, Flood JA, Schlievert PM, WangWeigand SZ, Osborn TW. In vivo assessment of human vaginal oxygen and carbon dioxide levels during and post menses. J Appl Physiol (1985). 2005; 99(4):1582-91.

18. Wagner $G$, Bohr L, Wagner P, Petersen LN. Tampon-induced changes in vaginal oxygen and carbon dioxide tensions. Am J Obstet Gynecol. 1984; 148(2):147-50

19. O'Hanlon DE, Moench TR, Cone RA. Vaginal pH and microbicidal lactic acid when lactobacilli dominate the microbiota. PLoS One. 2013;8(11):e80074.

20. Wagner G, Levin RJ, Bohr L. Diaphragm insertion increases human vaginal oxygen tension. Am J Obstet Gynecol. 1988;158(5):1040-3.

21. Wagner $G$, Levin R. Oxygen tension of the vaginal surface during sexual stimulation in the human. Fertil Steril. 1978;30(1):50-3.

22. Gong Z, Luna Y, Yu P, Fan H. Lactobacilli inactivate Chlamydia trachomatis through lactic acid but not H2O2. PLoS One. 2014;9(9):e107758.

23. O'Hanlon DE, Moench TR, Cone RA. In vaginal fluid, bacteria associated with bacterial vaginosis can be suppressed with lactic acid but not hydrogen peroxide. BMC Infect Dis. 2011;11:200

24. Strus M, Brzychczy-Wloch M, Gosiewski T, Kochan P, Heczko PB. The in vitro effect of hydrogen peroxide on vaginal microbial communities. FEMS Immunol Med Microbiol. 2006;48(1):56-63.
25. Rabe LK, Hillier SL. Optimization of media for detection of hydrogen peroxide production by lactobacillus species. J Clin Microbiol. 2003;41(7):3260-4.

26. St Amant DC, Valentin-Bon IE, Jerse AE. Inhibition of Neisseria gonorrhoeae by lactobacillus species that are commonly isolated from the female genital tract. Infect Immun. 2002;70(12):7169-71.

27. Ravel J, Gajer P, Abdo Z, Schneider GM, Koenig SS, McCulle SL, Karlebach S, Gorle R, Russell J, Tacket CO, et al. Vaginal microbiome of reproductive-age women. Proc Natl Acad Sci U S A. 2011;108(Suppl 1):4680-7.

28. Condon S. Aerobic metabolism of lactic acid bacteria. Irish Journal of Food Science and Technology. 1983;7(1):15-25.

29. Vaneechoutte M. Lactobacillus iners, the unusual suspect. Res Microbiol. 2017; 168(9-10):826-36.

30. Boskey ER, Cone RA, Whaley KJ, Moench TR. Origins of vaginal acidity: high $\mathrm{D} / \mathrm{L}$ lactate ratio is consistent with bacteria being the primary source. Hum Reprod. 2001;16(9):1809-13.

31. Wilson WA, Roach PJ, Montero M, Baroja-Fernandez E, Munoz FJ, Eydallin G, Viale AM, Pozueta-Romero J. Regulation of glycogen metabolism in yeast and bacteria. FEMS Microbiol Rev. 2010;34(6):952-85.

32. Aldunate $M$, Tyssen D, Johnson A, Zakir T, Sonza S, Moench T, Cone R, Tachedjian G. Vaginal concentrations of lactic acid potently inactivate HIV. J Antimicrob Chemother. 2013;68(9):2015-25.

33. Aldunate M, Srbinovski D, Hearps AC, Latham CF, Ramsland PA, Gugasyan R, Cone RA, Tachedjian G. Antimicrobial and immune modulatory effects of lactic acid and short chain fatty acids produced by vaginal microbiota associated with eubiosis and bacterial vaginosis. Front Physiol. 2015;6:164.

34. Hearps AC, Tyssen D, Srbinovski D, Bayigga L, Diaz DJ, Aldunate M, Cone RA, Gugasyan R, Anderson DJ, Tachedjian G. Vaginal lactic acid elicits an antiinflammatory response from human cervicovaginal epithelial cells and inhibits production of pro-inflammatory mediators associated with HIV acquisition. Mucosal Immunol. 2017;10(6):1480—90.

35. Mitchell C, Fredricks D, Agnew K, Hitti J. Hydrogen peroxide-producing lactobacilli are associated with lower levels of vaginal interleukin-1beta, independent of bacterial Vaginosis. Sex Transm Dis. 2015;42(7):358-63.

36. Graver MA, Wade JJ. The role of acidification in the inhibition of Neisseria gonorrhoeae by vaginal lactobacilli during anaerobic growth. Ann Clin Microbiol Antimicrob. 2011;10:8.

37. Nardini P, Nahui Palomino RA, Parolin C, Laghi L, Foschi C, Cevenini R, Vitali B, Marangoni A. Lactobacillus crispatus inhibits the infectivity of Chlamydia trachomatis elementary bodies, in vitro study. Sci Rep. 2016;6:29024.

38. Valore EV, Park CH, Igreti SL, Ganz T. Antimicrobial components of vaginal fluid. Am J Obstet Gynecol. 2002;187(3):561-8.

39. Breshears LM, Edwards VL, Ravel J, Peterson ML. Lactobacillus crispatus inhibits growth of Gardnerella vaginalis and Neisseria gonorrhoeae on a porcine vaginal mucosa model. BMC Microbiol. 2015;15:276.

40. Antonio MA, Hawes SE, Hillier SL. The identification of vaginal lactobacillus species and the demographic and microbiologic characteristics of women colonized by these species. J Infect Dis. 1999;180(6):1950-6.

41. Witkin SS, Mendes-Soares H, Linhares IM, Jayaram A, Ledger WJ, Forney LJ. Influence of vaginal bacteria and D- and L-lactic acid isomers on vaginal extracellular matrix metalloproteinase inducer: implications for protection against upper genital tract infections. MBio. 2013;4(4):e00460-13.

42. France MT, Mendes-Soares H, Forney LJ. Genomic comparisons of lactobacillus crispatus and lactobacillus iners reveal potential ecological drivers of community composition in the vagina. Appl Environ Microbiol. 2016;82(24):7063-73.

43. Nunn KL, Wang YY, Harit D, Humphrys MS, Ma B, Cone R, Ravel J, Lai SK. Enhanced trapping of HIV-1 by human Cervicovaginal mucus is associated with lactobacillus crispatus-dominant microbiota. MBio. 2015; 6(5):e01084-15.

44. Tomas J, Zonenschain D, Morelli L, Nader-Macias ME. Characterisation of potentially probiotic vaginal lactobacilli isolated from Argentinean women. Br J Biomed Sci. 2005;62(4):170-4.

45. Gajer P, Brotman RM, Bai G, Sakamoto J, Schutte UM, Zhong X, Koenig SS, Fu L, Ma ZS, Zhou X, et al. Temporal dynamics of the human vaginal microbiota. Sci Transl Med. 2012;4(132):132ra152.

46. Tomas MS, Bru E, Nader-Macias ME. Comparison of the growth of hydrogen peroxide production by vaginal probiotic lactobacilli under different culture conditions. Am J Obstet Gynecol. 2003;188(1):35-44.

47. Hütt P, Lapp E, Štšepetova J, Smidt I, Taelma H, Borovkova N, Oopkaup H, Ahelik A, Rööp T, Hoidmets $D$, et al. Characterisation of probiotic properties in human vaginal lactobacilli strains. Microb Ecol Health Dis. 2016;27:30484. 
48. Ranjbar $\mathrm{S}$, Holmes $\mathrm{H}$. Influence of hydrogen peroxide on the in vitro infectivity of human immunodeficiency virus. Free Radic Biol Med. 1996; 20(4):573-7.

Submit your next manuscript to BioMed Central and we will help you at every step:

- We accept pre-submission inquiries

- Our selector tool helps you to find the most relevant journal

- We provide round the clock customer support

- Convenient online submission

- Thorough peer review

- Inclusion in PubMed and all major indexing services

- Maximum visibility for your research

Submit your manuscript at www.biomedcentral.com/submit 